\title{
Journalists like the rest of them? A case study of journalistic work routines at a Danish free newspaper
}

\author{
Kirsten Sparre, Danish School of Media and Journalism \& Department of Media Studies \\ and Journalism, School of Communication and Culture, Aarhus University, Denmark \\ (mail: ksp@cc.au.dk)
}

\begin{abstract}
Academics have paid little attention to the practice of journalism at free newspapers since the free daily press emerged in 1995. A few studies have looked at the contents of free newspapers but not at the way journalism is practiced at free newspapers and whether these practices are different from journalistic work routines in the paid press. This article addresses that gap with a case study of the Danish free newspaper Metroxpress. After identifying the economic, political and digital forces shaping the contents at Metroxpress, the article maps the newspaper's news net, analyse efforts put into newsgathering and compare them to the newsgathering efforts of other Danish newsbrands. Findings indicate that while the news net is smaller than those of other Danish newspapers, journalists at Metroxpress have similar work routines to other journalists, and their work is routinely recognised by peers in the form of quotations and nominations for professional awards.
\end{abstract}

\section{Keywords}

free newspapers, news net analysis, market-driven journalism, metroxpress

\section{Introduction}

Somewhat surprisingly academics have paid little attention to the quality and practice of journalism at free newspapers since the free daily press emerged and disrupted newspaper markets in the mid1990 's. So it was both pertinent and timely when the organisers of the conference "The free daily press in Europe 1995-2015" called for an examination of journalism in free newspapers by asking whether the professional routines of journalists working for free newspapers are different from those of their colleagues employed in the traditional paid press? The call grew out of a concern that the commercial rather than publicist basis of free newspapers affects the quality of the work carried out by journalists employed there - a point conference organisers condensed into a further question, namely whether "journalists working for free newspapers still belong to the journalistic profession or are they mere economic agents separate from the rest of the media sphere?" (The Free Daily Press, n.d.)

Currently, academic research offers little help in answering such questions. So far, most of the research on free newspapers has been concerned with how the business model of free newspapers has fitted into national and crossborder newspaper markets (e.g. Bakker, 2013; Haller, 2009; Lamour, 2016), who their readers are (e.g. Bakker, 2007a; Wadbring, 2007), how that readership impacts on overall consumption of printed newspapers (e.g. Bakker, 2008; Wadbring, 2003) and the value that free newspaper content might have for readers (e.g. Kammer, 2010).

The most recent academic examinations of journalism at free newspapers were carried out by Bakker (2007b) and Wadbring (2009) at the height of the circulation of free newspapers before the decline began around 2008 (Bakker, 2013). Based on extensive readings of free newspapers from many countries, Bakker concluded that free daily newspapers 
generally provide an adequate account of current affairs, do some original reporting and is much more than a printout of national wire services (Bakker, 2007, p. 28). Wadbring reached similar conclusions in a study from 2009 of four different free newspapers published in Sweden. Based on content analysis, she found that the contents covered a wide range of issues in a factual and brief manner but without much depth. The newspapers contained a number of independently produced articles and were neither tabloid nor full of celebrity news (Wadbring, 2009).

Neither of these studies looked at the working routines of journalists at free newspapers, how they compare to working routines of journalists working for different types of newspapers, and whether journalists working for free newspapers can be considered part of the wider journalistic profession. However, it is exactly these questions this article sets out to explore through a case study of the Danish free newspaper Metroxpress. The case study places Metroxpress in the context of current economic, political and digital forces that are shaping the production of journalism at the newspaper, and then maps the newspaper's news net (Tuchman, 1978) to uncover its strategic approach to newsgathering for its intended audience, the resources invested, and its key journalistic concerns. It proceeds to analyse how much work journalists at Metroxpress put into their newsgathering and compare these results with findings about newsgathering efforts from a 2015 cross media survey of journalistic quality in Denmark (Willig, Blach-Ørsten, Hartley, \& Flensburg, 2015). A final theme in the article is peer recognition of the work carried out by journalists at Metroxpress. Are articles by journalists at Metropress quoted by other journalists, and are peers prepared to nominate journalists from Metroxpress for prestigious journalism awards?

\section{Context: economic, political and digital developments}

Bakker (2015) has provided a succint overview of the rise and fall of free newspapers in Denmark in the period from 2001 when Metroxpress was launched as the first free daily newspaper in Denmark to 2013 where Metroxpress became the last remaining Danish free daily. In the intervening years, nine other free dailies with a number of different editions have been launched and closed down again. However, the Metroxpress of 2017 differs in many ways from the Metroxpress of 2001. It has undergone a number of changes in ownership and responded to digital developments with new media platforms which coupled with political changes in the surrounding media system all have impacted on the newspaper's editorial approach to news coverage.

\subsection{Changes in ownership}

Metroxpress has had a string of different owners and been passed from one media group to the next since it was launched in 2001 in co-operation between the Swedish media group Metro owned by Kinnevik and the Danish media group A-Pressen that owned 30 percent of the company's shares (Søllinge, n.d.)

In 2008, Metroxpress was merged with the Danish free newspaper, 24timer, when its publishers, Danish media group JP/Politikens Hus, bought 49 percent of the shares in Metroxpress ("Metroxpress merges", 2008). Metroxpress and JP/Politikens Hus continued to publish the two different free newspapers that increasingly shared editorial resources ("Gratisaviserne 24timer og Metroxpress”, 2010).

In 2013, 20 Minuten AG - part of the Swiss media group Tamedia - bought all the shares in Metroxpress A/S and for a while cut all ties between free daily newspapers and Danish legacy media organisations ("Swiss 20 Minuten AG", 2012). Tamedia quickly decided to close down the free newspaper 24timer and instead focused all its resources on Metroxpress. In April 2013 Metroxpress and the website $\mathrm{mx} . \mathrm{dk}$ were relaunched in a new for- 
mat, with a new layout, a new distribution strategy, a new editorial line and expanded its journalistic staff to 40 with the specific objective of improving the quality of the journalistic output (Andreassen, 2013; “Metroxpress relanceres", 2013).

Since 2013, Metroxpress has had a monopoly position in the Danish market for free daily newspapers which cemented an already existing movement for Metroxpress to be a national newspaper rather than a newspaper exclusive to urban centres such as Copenhagen and Aarhus. The newspaper is produced in two geographical editions for East and West Denmark respectively that differ only on a few pages with localised content. The newspaper is distributed through partnerships with train and bus companies, supermarkets, shopping centres, schools and private companies. Currently, Metroxpress can be picked up in 3,592 different places across the country ("Danmarks mest læste", n.d.)

Tamedia has not succeed in making Metroxpress profitable and the newspaper has incurred major annual deficits since 2013. In 2014, the deficit was 67.8 million Danish kroner (9.9 million Euro), and in 2015 the deficit was 43 million Danish kroner (5.7 million Euro) (Carlsen, 2015; Madsen, 2016). In November 2016, Metroxpress was merged with the Danish tabloid newspaper BT into a company called BTMX. 30 percent of the shares in the new company are owned by Tamedia, and 70 percent of the shares belong to BT's owners, Berlingske Media Group (Walsh, 2016). Through this merger, the only free Danish newspaper has once again become part of a legacy media organisation with the explicit objective to strenghten the position and reach of BT as well as Metroxpress (ibid.). The two papers now share one editorial office and have lost around 14 editorial staff members between them (Skadhede, 2017).

This brief overview of changes in ownership of Metroxpress illustrates how difficult it is to make free newspapers profitable and how different media groups have applied different strategies in their attempts to attain that goal. In those attempts, different owners have set different frameworks for the journalistic work at
Metroxpress either adding more resources or diminishing them by asking journalists to produce content for more than one newspaper. This constantly changing framework where numbers of journalists contract or expand is an important factor to consider when talking about the quality of journalistic work at the newspaper.

\subsection{Media systemic frameworks for journalistic content}

The Danish media system also provides a specific framework for journalistic work where newsbrands are not completely free in deciding the composition of editorial contents - particularly if they want to obtain press subsidies from the Danish state. Firstly, there is a limit to the number of articles that subscribers to the dominating Danish news agency, Ritzau, can publish on a daily basis. According to an agreement between Ritzau and The Danish Competition and Consumer Authority, only 40 per cent of a newspaper's content on any given day may consist of articles from the Ritzau news agency ("Anmeldelse af Ritzaus aftale", 2005). This means that a free newspaper can not rely solely on news agency material (unless it subscribes to other news agencies than Ritzau), but must also produce its own material.

Secondly, newspapers that want to apply for press subsidies must also live up to a number of other quantitative criteria set by the new law on media subsidies that the Danish parliament passed in 2013.

The new law changed the premise for state subsidies to the written press away from subsidies for distribution towards subsidies for production (Flensburg, 2015). In a review of the Danish press subsidy measures since 1960, Flensburg points out that the new law reflects that politicans were increasingly loosing faith in the abilities and commitment of Danish media organisations to produce quality content on their own accord, and therefore politicians used the new media subsidy scheme to affect the production of content of public interest (ibid.).

The specific criteria for obtaining funding quantify journalistic quality on a 
number of different parameters ("Vejledning til ansøgning”, 2015):

> In terms of organisational set-up, the media organisation must have the equivalent of at least three full time editorial staff and an editor-in-chief.

, In terms of content, at least half of the contents in the publication measured in column inches should be editorial in the form of articles and other journalistic formats.

, More than half of the editorial content should deal with political, social, and cultural themes on a regular basis.

, At least one sixth of the contents of the publication should be produced specifically for the publication - i.e. be original production. Unedited or lightly edited material from news agencies are not counted as part of the publication's original production.

The change in the media subsidy scheme has had serious financial implications for Metroxpress. Under the previous scheme Metroxpress received approximately 20 million Danish kroner annually to support their distribution efforts. Today, Metroxpress only receives approximately 6.5 million Danish kroner annually to offset some of the costs of producing journalistic content of a certain standard (Albrecht, 2014). However, for the purposes of this discussion, the interesting point is that Metroxpress does meet politically agreed quality criteria for obtaining subsidies to produce journalism.

\subsection{Changes to journalism from digitalisation}

Digitalisation has opened up new avenues for attracting readers and thereby advertising which are also utilised by Metroxpress. Today, Metroxpress is best described as a newsbrand that publishes news and generates advertising income from a number of different platforms:

, Print: The newspaper Metroxpress is published on weekdays 5 days a week, and the special edition Plus+ is pub- lished on selected Saturdays and holidays throughout the year

, Digital: Metroxpress has its own website: $m x$.dk with articles and video clips

Social: Metroxpress has a number of topic-based pages on Facebook as well as accounts on Twitter, Google+, Instagram and Snapchat

, Television: In 2014, Metroxpress started to deliver news, entertainment and advertisments to the television screens on the urban S-train network around the Danish capital (Bilberg, 2014)

The growing number of platforms has led to changes in the way journalistic work is organised and conceptualised at the newspaper. In February 2015, the newspaper set up a social media desk with 11 journalists and announced that it was adopting a "social media first" instead of "web first" strategy. In a press release, the editor-in-chief, Simon Stilling, explained that platforms such as Snapchat, Facebook and Twitter were crucial in terms of reaching young users and therefore social media should be an integrated part of all news production at Metroxpress (Bilberg, 2015). The move had important journalistic implications with regards to news selection and according to Stilling, the newspaper should now publish fewer hardcore news stories and crime stories in favour of stories that raise ethical or moral dilemmas (Bitsch, 2015a).

Inspired by media such as Buzzfeed and Vox.com, Metroxpress also developed five so-called social criteria that can be applied to hardcore news stories at the point of conception in order to make such stories more palatable for the young audience that the newsbrand wants to reach by posting the stories on social media. The criteria are: It is about me; it seduces me; it evokes a feeling; it makes me want to get involved; and WTF (What the $\mathrm{f}^{* *} \mathrm{k}$ ?) (Bitsch, 2015b).

\subsection{Editorial approach and readership}

Describing its own target group to potential advertisers, Metroxpress explains that it produces content for 
... the 15-39 year old modern and busy urbanites who want to read about the most important news in a youthful and entertaining way. ... Our readers have many irons in the fire and are always on the move. They want to be kept up to date with short news items that surprise and excite them and keep them on the cutting edge of important debates. ... ("Danmarks mest læste", n.d.)

Consequently, the newspaper produces news items that are "short, precise and never boring" and covers the most important news from Denmark and abroad as well as more entertaining stories that lend themselves to be shared both in person and on social media ("Om os", n.d.).

Under this very broad heading, Metroxpress has implemented some significant developments of journalistic practices since the relaunch in 2013. That includes a decision to produce at least one agenda-setting story per day and allocating more time for each story to include more sources (Andreassen, 2013). The ambition was that Metroxpress should be able to produce unique and independent journalism that could be nominated for professional journalistic awards. It was a significant change in the way Metroxpress had looked at the functions of its own journalism up to this point, the new editor-in-chief, Simon Stilling explained:

In a way, we want to introduce a completely new journalistic identity at the newspaper. So far, Metroxpress has mainly provided a news overview, but now we also want to do the stories that lead to debate in society. We must continue to be the best on rolling news but also on independent news that can set an agenda. (ibid.)

Since the relaunch of the Metroxpress newspaper in April 2013, the number of readers has grown considerably and continues to do so. At the time of the relaunch, the newspaper had 350,000 readers, and by 2016 that number had risen to 509,000 readers ("Profil af Metroxpress' læsere", n.d.) This is by far the highest number of readers for any Danish newsbrand. The two daily quality newsbrands that come closest are Politiken (285,000 readers) and Jyllands-Posten (204,000 readers) (ibid.). The circulation of Metroxpress is approximately 330,000 copies ("Distribution", n.d.).

On the web, mx.dk is also attracting more users since the relaunch in April 2013, and by September 2016, mx.dk had 821,000 users per month ("Profil af mx.dk", n.d.). However, on the web, Metroxpress does not dominate in terms of users. In September 2016, a number of other news websites had more users than mx.dk including the websites for the two national television stations, a tabloid newsbrand and a quality newsbrand ("Toplisten", n.d.).

Readers of the newspaper version of Metroxpress are divided almost equally between men $(51 \%)$ and women $(49 \%)$. The majority of the readers are over 30 years old with 41 percent in the group aged $30-59$, and 33 percent in the group aged $60+.26$ percent - around a quarter - of the newspaper's readers are in the age group 12-29 ("Profil af Metroxpress's læsere", n.d).

The newspaper is more successful in attracting younger readers on the web. The group of 12-29 year olds make up 43 percent of web users, the age group 30-59 42 percent and those over 60 the remaining 6 percent. There are more women than men among the users of mx.dk. Women make up 54 percent of the users and men the remaining 46 percent ("Profil af mx.dk", n.d.).

\section{Research design}

In order to discuss whether journalists working for a free newsbrand employ methods similar to their colleagues in other media and are considered part of the broader journalistic profession in Denmark, I use a number of different methods which I will outline in more detail below after a brief overview. The different parts of the analysis supplement each other but also form an arc of progression.

To establish a baseline for the discussion, I undertake a news net analysis of one 
week's journalistic production at Metroxpress. Analysing the news net enables us to understand how journalistic production is structured at the newspaper, the journalistic resources involved, and the type of content the newspaper emphasises.

While a news net analysis provides an understanding of the topics covered by Metroxpress and how many articles are produced on weekly basis, it says nothing about the quality of the work performed by journalists and how it might be influenced by underlying commercial norms. This aspect will instead be explored through an analysis of the newsgathering efforts at Metroxpress inspired by work by John H. McManus (1994). Findings from this analys will then be compared to findings from a large scale and cross media analysis of quality in Danish journalism (Willig et al., 2015) that employed the same methods, to see if and how newsgathering efforts differ between Metroxpress and other Danish media organisations.

Finally, I will approach the question of inclusion in the broader journalistic profession through an analysis of peer recognition in the form of nominations for journalistic awards and citations of articles from Metroxpress in other media.

\subsection{Empirical data}

First, however, I want to introduce the empirical basis for the analyses of the news net and newsgathering efforts below. The data consists of all news items published in the five issues of Metroxpress (edition East) produced from Monday 9 November 2015 to Friday 13 November 2015.

The newspaper is the flagship of the Metroxpress newsbrand and much of the content is re-used on other platforms, which makes the newspaper a suitable site for observing journalistic practices at Metroxpress. News items are defined as content produced by journalists, whereas content supplied by readers, crosswords, cartoons, horoscopes, weather forecasts, TV listings and lists with sports results have been excluded.

The week from 9-13 November 2015 was week 46 , and this particular week has been used in Denmark for cross media re- search on news production by a number of different researchers since 2000 (Lund, 2000; Lund, Willig, \& Blach-Ørsten, 2009; Sparre and Kabel, 2001) and most recently in an extensive cross media report on journalistic quality in Danish media produced for the Danish Agency for Culture and Palaces (Willig et al., 2015). The week is considered to be a "normal" week in the sense that it is outside the holiday season, and November is generally not the time of year where special events are scheduled that could affect day-to-day news coverage in ways that are likely to distort research findings. In the context of this project, choosing week 46 also makes it easier to compare findings from this analysis with those from the 2015 report mentioned above.

\subsection{Mapping the news net}

The term "news net" was coined by Tuchman (1978) as a way to describe how a news organisation organises the process of gathering the material that can be turned into news. One set of strings in the news net are made up by the resources employed by the news organisation to gather information such as its own employees, news agencies, freelancers or various partnerships. The news organisation then divides the world into areas of responsibility and creates a second set of strings by identifying and allocating resources to the topics, organisations, or geographical localities that the news organisation believes its audience is interested in hearing news about.

As Tuchman pointed out the news net is specific for each news organisation:

\footnotetext{
The actual divisions used by any specific news organization replicates the organization's notion of its news mission - what it believes its particular readers want to know and what it is financially prepared to give them. (Tuchman,1978, p. 25-26).
}

The organisation of Metroxpress' news net was determined through the registration for each news item of the section it was published in (e.g. News or Celebrities) as well the author of the news item and how that author was connected to Metroxpress. 
Authors were identified and placed in one of the four categories below:

> A news agency - identified by bylines or initials such as Ritzau, RB, AP or AFP

> A journalist employed by Metroxpress identified through the byline including a direct Metroxpress mail address, or the initials of the journalist

, A freelance journalist - identified through initials or a byline without a direct Metroxpress mail address and corroborated by LinkedIn-profiles stating that the journalist is a freelance journalist

, A journalist working for a Metroxpress partner - identified on pages clearly labelled as produced by a partner and through initials or a byline without a direct Metroxpress mail address

\subsection{Newsgathering efforts}

In order to analyse the work routines of journalists at Metroxpress, I will look at newsgathering efforts. This approach to analysing journalism was first introduced by John H. McManus in his book "Market-Driven Journalism: Citizens Beware?” (1994) and has later been adapted by other researchers.

In his research, McManus asked whether the selection of journalistic content was better explained by a market model or a journalistic model. In one approach to deducing which selection model offered the best explanation, he studied how much effort journalists at three TV-stations in California put into discovering the information that turned into news reports. If news is a commodity only, the production of news should follow a market logic and provide the least expensive mix of content by letting reporters find the news in other media, news agencies or press releases. If news has a public service component, journalistic logic would dictate the need to employ more active means of discovering the news such as placing journalists in various locations to cultivate sources and learn what might be useful for the audience (McManus, 1997). This idea of distinguishing between levels of discovery has later been adopted and adapted by other researchers, including the authors of a special report on journalistic quality in Danish media 1999-2014 (Willig et al., 2015). In this report, researchers couple levels of discovery with the provenance of individual news items, and in order to facilitate cross media comparison between their findings and my findings from $\mathrm{Me}$ troxpress, I have adopted part of the coding manual from that project. So the 316 news items from week 46 in 2015 have all been placed in one of the categories below:

Agency material: Stories that come to the journalist via a subscription to a news agency and therefore requires no active discovery and only minimal editing. Can be identified through bylines or agency initials.

Service journalism: Stories where the idea and/or source is found in other media reports or press releases. These stories require a minimal degree of discovery as they can be researched with the help of computer and an internet connection and without leaving the office. Can be identified through the sources journalists refer to in the article.

Routine journalism: Stories that are produced by the newspaper's own journalists but are not given much space or considered focus journalism (see below). Routine journalism can also be reports from news events such as press conferences.These stories require a moderate degree of discovery as the journalists will need to identify and contact sources or attend events outside the newsroom. Can be identified through bylines, choice of genre (for instance reportage or interviews) and the references journalists make to sources in the article.

Focus journalism: Stories that are the result of a concerted effort by the newspaper's journalists. The stories can be developed independently or in cooperation with an outside partner. The stories are based on highly active discovery as they often include time consuming research such as surveys, tests or applications for access 
to official documents. Can be identified through references to time consuming research efforts and the way the newspaper frames the story as important in the article (e.g. placement in the newspaper, labels, self-promotion).

I continue the exploration of newsgathering efforts by drawing on findings from the special report on journalistic quality in Danish media 1999-2014 in order to make two different comparisons. The first is a comparison between Metroxpress's newsgathering efforts in 2015 and 2012 in order to determine the effects of Metroxpress's decision to employ more journalists in 2013. The second is a comparison between the newsgathering efforts of Metroxpress and those of a number of other media organisations in Denmark to see if the working routines of journalists at Metroxpress differ significantly from those working for other news organisations.

\subsection{Inclusion in the broader journalistic profession}

In order to explore the degree to which journalists working for Metroxpress are considered part of the broader journalistic profession in Denmark, I am going to look at two different types of recognition that journalistic peers can bestow on Metroxpress journalists.

One form of peer recognition is the degree to which journalistic products from a given news organisation becomes part of what Lund has called the food chain of news (Lund, 2000). The food chain of news is a metaphor for how news stories from one news organisation is incorporated into or picked up as complete news stories by another news organisation. In this process, journalists from other news organisations validate the work of the original author by accepting some or all of the professional choices made with regards to angling, sourcing and writing the news story in question.

The Danish industry news site, Media Watch, publishes monthly as well as annual quotation indexes based on information in the database Infomedia that contains editorial content from almost all Dan- ish journalistic media. The index makes it possible to see how often stories from Metroxpress are quoted in 14 different national newsbrands and a selected number of TV and radio programmes, and how the number of Metroxpress quotations compare to quotation numbers of other media.

Another form of peer recognition takes place when journalists nominate each other for professional journalistic awards. Two of the most prestigious journalism awards in Denmark are the Cavling Prize and awards from the Danish Association of Investigative Journalism, and I look at the nominations for the years 2014, 2015 and 2016 to see if journalists from Metroxpress were among those nominated.

\section{Findings}

The findings presented in this section will take us from understanding the contents and journalistic resources invested in $\mathrm{Me}$ troxpress over comparisons of journalistic work routines at Metroxpress and other Danish media to an appreciation of how journalistic work by Metroxpress journalists is evaluated by their journalistic peers at other media.

\subsection{A small news net}

We start with the news net analysis for week 46 in 2015 presented in table 1.

The column on the left shows the sections of the newspaper and whether the particular section was published daily or weekly. The number in brackets after the short description of the contents of the section shows the total number of articles published in that section during week 46 .

The top row shows four different types of authors of news items as well as the percentage of articles that this particular group of authors produced during week 46.

The percentages inside the table shows how many of the articles published in a particular section that were produced by that specific group of authors.

As table 1 shows, the news net at Metroxpress is small both in terms of topics covered and in terms of resources. During 
Table 1: $\quad$ The news net of MetroXpress

\begin{tabular}{|c|c|c|c|c|}
\hline News net MetroXpress, week 46/2015 & $\begin{array}{r}\text { Agencies } \\
41 \% \\
\end{array}$ & $\begin{array}{r}\text { Employees } \\
49 \% \\
\end{array}$ & $\begin{array}{r}\text { Freelancers } \\
3 \% \\
\end{array}$ & $\begin{array}{r}\text { Partners } \\
7 \% \\
\end{array}$ \\
\hline \multicolumn{5}{|l|}{ Daily sections } \\
\hline News: the most important news ( 40 items) & $70 \%$ & $30 \%$ & & \\
\hline Copenhagen: local and regional news (19 items) & $16 \%$ & $84 \%$ & & \\
\hline Denmark: politics, culture, crime, lifestyle (45 items) & $60 \%$ & $40 \%$ & & \\
\hline Global: politics, culture, crime, lifestyle (49 items) & $88 \%$ & $12 \%$ & & \\
\hline Money: work, consumer spending (23 items) & $4 \%$ & $96 \%$ & & \\
\hline Feed: news about social media (20 items) & & $100 \%$ & & \\
\hline Celebrities: news about celebrities ( 31 items) & & $100 \%$ & & \\
\hline Sport: Danish and international sports (49 items) & $53 \%$ & $47 \%$ & & \\
\hline \multicolumn{5}{|l|}{ Metroxpress: photos from readers (n/a) } \\
\hline \multicolumn{5}{|l|}{ Weekly sections } \\
\hline Music: news and reviews of music ( 5 items) & & $60 \%$ & $40 \%$ & \\
\hline Digital: news and reviews of digital hardware and games (7 items) & & & & $100 \%$ \\
\hline Fashion: news about the fashion industry and new styles ( 5 items) & & $20 \%$ & & $80 \%$ \\
\hline Film: news and reviews of new movies ( 3 items) & & & $100 \%$ & \\
\hline City night life: news about upcoming night time events (4 items) & & $100 \%$ & & \\
\hline Science: natural and social science news (9 items) & & & & $100 \%$ \\
\hline Television: news about the industry and programmes ( 4 items) & & & $100 \%$ & \\
\hline Travel: news about travelling and destinations ( 2 items) & & & & $100 \%$ \\
\hline Huxi Bach: column by a political satirist (1 item) & & & $100 \%$ & \\
\hline
\end{tabular}

week 46 the newspaper published a total of 316 items which equals approximately 63 news items per day. In this particular week, the topical strings of the news net was made up by nine daily sections and nine sections that were published once during the week. In November 2015, Metroxpress employed 40 journalists ("Om os”, n.d.) who between them produced 49 percent of the 316 news items. The rest was produced by freelancers, partners and by news agencies - the latter accounted for 41 percent of all news items.

The news net is a construction that is equally interesting for what it includes as for what it excludes. The news net of Metroxpress covers the main Danish and global news as well as sports news and adds a number of primarily lifestyle sections that the newsbrand considers to be of interest to its young and urbanite readership such as digital and social media, celebrities, film and TV, travelling, fashion, music, science and money matters. However, none of these topics are covered in any considerable depth neither in terms of the number of articles nor in terms of the use of genres. The vast majority of stories belong to the news genre, and week 46 only contains a few examples of other genres such as profiles, reviews and reportage.

What is not present in the news net are elements which can be found in traditional omnibus newspapers that consider an important part of the role of journalism to be to enable readers to act as informed citizens on election day and to provide a forum for debate. Opinions in the form of columns are largely absent, and the newspaper's political commentator is interviewed by journalists and does not write his own comments. There are no letters to the editor, and no daily editorial as the newspaper considers itself to be apolitical (ibid.)

In view of the heavy reliance on outside producers, it is interesting to see where in the news net Metroxpress focused its own resources. In week 46 , all stories in the daily sections Feed and Celebrities were produced by Metroxpress' own journalists, 
and the sections Copenhagen and Money were closely behind with respectively 84 and 96 percent of contents produced by Metroxpress journalists. In the daily sections News, Denmark, and Sports content production was divided more evenly between news agencies and Metroxpress journalists whereas content in the section called Global mainly came through news agencies (88\%).

The majority of newsbrands in Denmark uses news agencies to cover foreign affairs in lieu of employing their own foreign correspondents, and in this respect Metroxpress is not different from most other newsbrands. However, Metroxpress uses news agencies strategically when it comes to covering events in Denmark too. Subscribing to the main Danish news agency, Ritzau, means that Metroxpress does not need to use its own journalists for routine monitoring of those sources that Fishman (1980) has labelled bureaucratic sources: The police, the courts, and the day to day workings of the political system at national, regional and local levels. This work is left to the news agency, and Metroxpress picks up only those stories it considers interesting and places them mainly in the sections News and Denmark where they contribute to creating the quick news overview that is part of Metroxpress' objectives. News agency material is also used extensively in the highly prioritised sports section to cover international sports events as well as Danish sports results.

Meanwhile, Metroxpress uses its own journalistic resources to produce agenda-setting stories and the content that appeals specifically to its key target groups both in terms of content matter and social relatability. The finding confirms the intentions expressed by editor-in-chief, Simon Stilling, that "we give priority to the stories we believe contribute to the identity of Metroxpress and then we leave the rest to Ritzau" (Bitsch, 2015 a).

\subsection{Newsgathering efforts at Metroxpress}

The news net analysis has shown that journalists at Metroxpress produce a fairly limited amount of news items per day but it says little about how much work has been put into the production of the individual news items. But that is precisely the question that is addressed in the analysis of newsgathering efforts.

Table 2 shows the distribution of the 316 news item from week 46 in the four different categories of newsgathering efforts described in the section on research design. The two columns on the left show the distribution of all the week's news items, and the two columns on the right show how the articles produced by Metroxpress' own journalists were distributed among the categories.

Table 2: Newsgathering efforts, Metroxpress 2015

\begin{tabular}{l|r|r|r|r}
\hline & Items & $\begin{array}{r}\text { Percentage } \\
\text { of all } \\
\text { content }\end{array}$ & $\begin{array}{r}\text { MX own } \\
\text { production }\end{array}$ & $\begin{array}{r}\text { Percentage } \\
\text { MX pro- } \\
\text { duction }\end{array}$ \\
\hline Agency material & 128 & $40.5 \%$ & $\mathrm{n} / \mathrm{a}$ & $\mathrm{n} / \mathrm{a}$ \\
Focus journalism & 12 & $3.8 \%$ & 12 & $6.3 \%$ \\
Routine journalism & 60 & $19.0 \%$ & 60 & $32.0 \%$ \\
Service journalism & 116 & $36.7 \%$ & 116 & $61.7 \%$ \\
\hline Total & 316 & $100 \%$ & 188 & $100 \%$ \\
\hline
\end{tabular}

77.2 percent of the contents in Metroxpress are produced using no or relatively little effort on the part of journalists at the newspaper (agency material and service journalism). Looking exclusively at MX's own production, the majority of news items are service journalism pieces (61.7\%), while 32 percent have required more effort. Stories developed exclusively by Metroxpress and/or requiring more extensive newsgathering efforts made up 6.3 percent of week 46's offerings to readers.

Service journalism items are produced utilising material that comes easily to journalists typically in the form of press releases, newsletters, other media websites, and general searches on the internet. Journalists normally credit their sources of information partly as a matter of professional courtesy and partly to boost the credibility of the story, and these sources were also coded as part of the registration of items produced by journalists from $\mathrm{Me}$ troxpress. 56 percent of all service news 
items quoted another media organisation as their source while 4.3 percent of the items referred to a social media source. So overall, a fair amount of the journalistic efforts were directed towards monitoring other media and finding news that had passed the gatekeeping processes there. It was not possible to ascertain the sources of information for the remainder of the service journalism items although many of them exhibited the signs of press releases or PR intervention through their use of single sources, positive framing, and close association with a product release or upcoming event (Erjavec, 2005). The main point here, however, is the observation that journalists at Metroxpress are not filling the pages mainly with PR material but are conducting independent research albeit from easily accessible sources.

Focus journalism made up 6.3 percent of the week's production and consisted mainly of the type of agenda-setting stories that Metroxpress decided to focus on after the relaunch in 2013.

In week 46, the dominant topic within the group of focus journalism articles was the HPV-vaccine and the way Danish society is dealing with the devastating side effects experienced by some young girls and women who have been injected with the vaccine. Week 46 marked the launch of an Metroxpress investigation into the safety of the vaccine, the treatment of those affected by the vaccine, and the links between the medical industry and doctors, organisations, authorities and the Danish and international agencies set up to monitor medical issues ("Stort HPV-tema”, 2015). HPV-related stories were front page news for four out of five days during week 46 with new developments every day. Another top story during the week was an investigation into the salaries of top managers in the five adminstrative regions in Denmark which showed that 14 of them were paid more than the Danish prime minister. In both cases, journalists at Metroxpress were carrying out watchdog functions with stories that were in the public interest. At the same time the articles fulfilled Metroxpress' ambition to raise moral and ethical dilemmas that get people talking, and in the case of the HPV-vaccine the articles were of particular interest to important target groups such as women and young people. Women and young people were also likely to be interested in a couple of that week's other focus journalism articles. One followed up on previous investigations of why only one in 60 cases of rape leads to a criminal conviction, and the other reported that the Danish Environmental Protection Agency will investigate a jewellery importer after tests carried out for Metroxpress had shown that the importer's jewellery contained illegal levels of cadmium and nickel.

Finally, a third of all MX production in week 46 were news items labelled routine journalism. These are stories that are conceived by journalists at Metroxpress - sometimes based on inspiration from other media or a press release - and then worked up using a number of sources from outside the newsroom.

Figure 1: Newsgathering efforts in 2012 and 2015

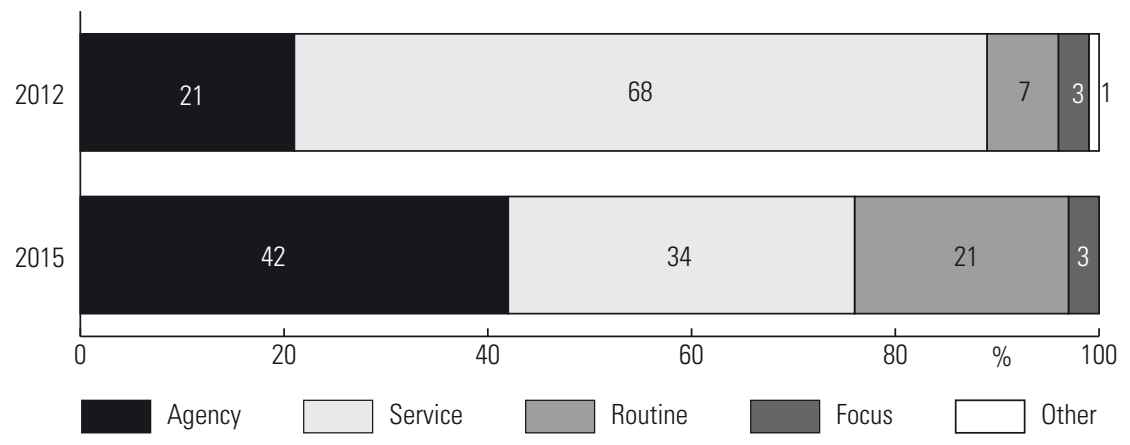


This was the kind of journalism that Metroxpress wanted to strengthen when it expanded the number of journalists working for the newsbrand after the relaunch in 2013, and by drawing on findings from the 2015 special report about journalistic quality in Danish media (Willig et al., 2015) it is possible to determine whether Metroxpress met that objective.

The 2015 special report only contains data about the distribution between the different levels of newsgathering efforts at Metroxpress from the Tuesday and Thursday editions in week 46, 2012. Therefore, in order to faciltate comparison between 2012 and 2015, I have also included only the data from the Tuesday and Thursday editions in 2015 in figure 1 above.

Figure 1 shows that the percentage of routine journalism items has tripled from 7 percent in 2012 to 21 percent in 2015 . The percentage of service journalism items has been halved from 2012 to 2015 (from 68 to 34 percent), and at the same time the percentage of agency items has doubled. The percentage of focus journalism was the same in the two years compared. In other words: The investment in more journalistic resources from 2013 did lead to higher production of more labour intensive news items but also to greater reliance on news agency material.

\subsection{Newsgathering efforts compared to other newsbrands}

The question is, however, whether Metroxpress is significantly different in its newsgathering efforts from other newsbrands. The 2015 special report about journalistic quality in Danish media (Willig et al., 2015) contains data from 2012 about the distribution between the different levels of newsgathering efforts at a wide range of Danish media. Figure 2 uses data from 2012 from four different groups of Danish newsbrands to establish a comparison with the 2012 figures from Metroxpress.

Figure 2 shows that the majority of original content produced by journalists employed by Danish newsbrands is service journalism, routine journalism is second, and focus journalism makes up only a small proportion of overall content. But there are wide variations on that theme, and the importance of news agencies for making up the contents of the final product also differs.

More than half of the content in all media types are produced with little or no newsgathering efforts on the part of journalists (agency and service journalism) but that percentage is significantly higher at Metroxpress than for other newspaper groups. However, as we saw in figure 1, the combined number of agency and service journalism items fell in Metroxpress from 2012 to 2015 in favour of more routine journalism that involve greater efforts on the part of journalists.

Considering the small number of staff at Metroxpress it is not surprising that the newspaper relies heavily on news produced with relatively little effort, but in the debate about the professional routines and quality of free newspapers compared to other newsbrands it is worth keeping in mind that all newsbrands are dominated by agency material and service journalism.

\subsection{Peer recognition: quotations}

According to the annual quotation index for 2015, news stories from Metroxpress were quoted 384 times over the year. The number is considerably lower than those of highly staffed quality newsbrands such as Politiken (2705 quotations), Berlingske (2360 quotations), and Jyllands-Posten (2219 quotations), but comparable to niche media with smaller staff numbers such as the Christian faith-based newspaper Kristeligt Dagblad (435 quotations) and the business news site Finans (416 quotations) (Carlsen, 2016).

Zooming in on the month of November 2015, Metroxpress was quoted 35 times by the national newsbrands and TV and radio which put it ahead of not only Kristeligt Dagblad (28 quotations) and Finans (15 quotations) mentioned above, but also the tabloid BT (30 quotations) and the business newsbrand Børsen (31 quotations) (Carlsen, 2015b).

Moreover, searches in the Infomedia database shows that Metroxpress stories from week 46 also were quoted in other types of media than the national news- 
Figure 2: Newsgathering efforts across media groups 2012

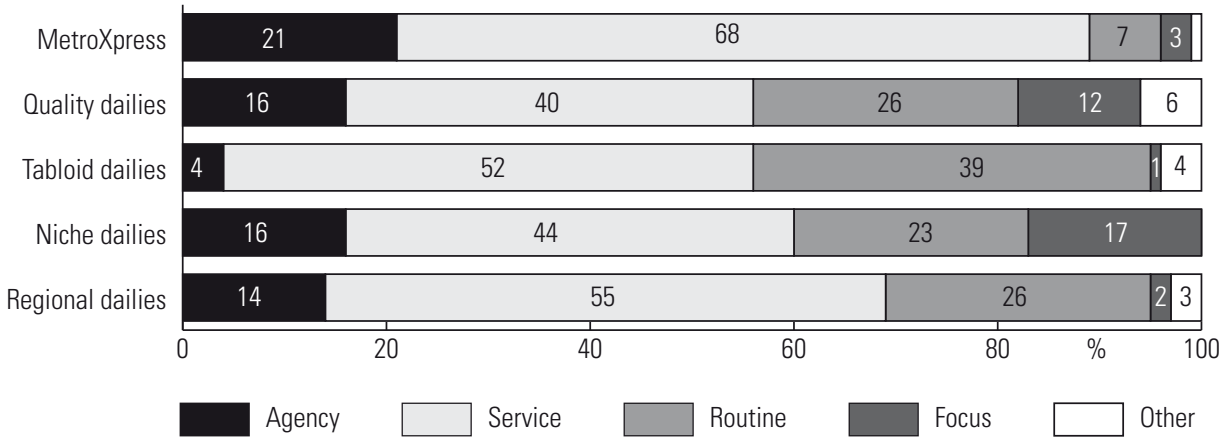

brands, radio and TV covered by Infomedia's quotation index. Four different stories were picked up by a news agency and later carried in some of the regional and local newspapers that subscribed to the news agency. Other takers were digital news sites, an industry news site and an online site for teenage girls.

The stories quoted belonged mainly to the category of routine journalism, and many of them were based on surveys or data made by other companies that Metroxpress either had exclusive access to or were the first to detect. That included a much-quoted story about the explosive rise in fitness related sports injuries based on data from an insurance company, another story that significantly fewer foreigners are granted Danish cititzenship today compared to 15 years ago, and a story based on statistics from the police that show an increasing number of arrests related to the buying and selling of illegal marihuana via phone and text messages. The focus story that moved into other media was the exposé of the inflated salaries paid to top administrators in the Danish administrative regions.

Taken as a whole, the relatively high number of quotations shows that Metroxpress is not only capable of producing journalism that is agenda-setting but also produce stories that routinely are picked up and quoted by other newsbrands including those with much higher staff numbers and prestige within the media world.

\subsection{Peer recognition: nominations for professional awards}

Each year, journalists can suggest their peers for the most prestigous Danish journalism award "The Cavling Prize" administered by the Danish Union of Journalists, as well as for awards from the Danish Assocation for Investigative Journalism. The ambitions of the editor-in-chief that journalism from Metroxpress should be good enough to be considered for professional journalistic awards have been met in 2014, 2015 and 2016.

One team of three journalists from Metroxpress were nominated twice for the Cavling Prize, in 2014 and 2015, for their long-running exposure of extreme financial mismanagement, nepotism and breaches of procurement rules in connection with the Eurovision Song Contest 2014 that was hosted in Copenhagen by the Danish Broadcasting Corporation in cooperation with the City of Copenhagen, the Capital Region of Denmark, and Wonderful Copenhagen ("Forslag til Cavlingprisen”, n.d.; Langergaard, 2014). The same team and project was also nominated for an award from the Danish Association for Investigative Journalism in 2014 (Bruun-Hansen, 2014).

In 2016, another journalist from Metroxpress was nominated for the Cavling Prize for a four year investigation into practices of brainwashing, exorcism, and sexual abuse in Danish free churches (“Cavlingforslag 2016”, n.d.) 
In 2015, two different projects from Metroxpress were nominated for an award from the Danish Association for Investigative Journalism. One project called "Only one out of 60" explored in a long series of articles the reasons why only one out of 60 rapes leads to a criminal conviction. The other project was an investigation into how much money Danish local authorities had spent on sending young addicts and criminals to the Caribbean for rehabilitation purposes with questionable results (Højsgaard, 2016).

So far, however, none of the nominees have actually won an award but the nominations show that work by journalists at Metroxpress has been recognised and appreciated by their peers working for other media organisations.

\section{Discussion and outlook}

This case study has shown that when it comes to practices and work routines of journalists at Metroxpress they are very similar to those of their peers working for other Danish news organisations even though Metroxpress is a very small news organisation that produces only a fraction of the content produced by bigger newsbrands. While the composition of the news content of Metroxpress is limited and different from other newsbrands in Denmark, the newspaper still covers the main daily news developments and also initiates independent reporting on a number of topics of particular interest to its predominantly young and female audiences. The articles produced by journalists at Metroxpress are an integrated part of the news food chain among Danish media, and peers recognise and value investigative reporting from Metroxpress.

Using McManus' terms, the case study also shows that the selection of news at Metroxpress does not follow a market model only where news is gathered at the lowest possible costs, but also appears to be influenced by a journalistic model. Metroxpress invests in investigative and focus journalism, just as the share of service journalism articles that can be produced at low costs from within the newsroom has been halved since 2012 in favour of more articles where journalists work up stories drawing on sources and events outside the newsroom.

But why would a free newspaper invest in higher quality journalism - particularly as it is not necessary to produce investigative journalism in order to obtain media support from the Danish state? One explanation can be found in looking at the areas where the investments have taken place. The analysis of the news net showed that Metroxpress focuses its editorial ressources and original production on the topics that appeal specifically to its readership. It is precisely those sections that now have more articles produced through routine journalism instead of mainly service journalism. Investigative and focus journalism articles can be found in different sections but they too have been selected to meet the specific interests of readers of Metroxpress. So overall, the investment in journalism takes place in the areas that brand Metroxpress and create most value for its readers.

As shown above, Metroxpress has been successful in attracting significantly more readers and users of its website since the relaunch in 2013, and it is a fair assumption that the growing popularity in part can be attributed to more content that the audience finds valuable and relevant. The relationship between readers/ users and the quality of journalism in Metroxpress has not been part of this analysis but is a highly relevant area for further research - not only in terms of understanding the relationship between journalism in free newspapers and their readers, but also because the findings will nuance the understanding of market and journalistic logics at free newspapers. A free newspaper is free at the point of consumption but being free does not guarantee readership. In an attention economy, irrelevant and low quality journalism will not give readers and users reasons to engage with a newsbrand even if it is free and that will directly undermine the newsbrand's advertisement driven business model. Today, a commercial logic for news production 
in free newspapers might imply a focus on better quality in newsgathering efforts rather than less to stand out in a media landscape with easy access to free news content in a wide range of media.

The findings of this case study appear to be at odds with the concerns embodied in the question of whether "journalists working for free newspapers still belong to the journalistic profession or are mere economic agents separate from the rest of the media sphere?" In Denmark, journalists working for Metroxpress are an integrated part of the broader journalistic profession which may in part be explained by the fact that Metroxpress like the majority of other Danish media has a collective agreement with the trade union for journalists and employs professional journalists ("Oversigt over overenskomster", n.d.). The situation for journalists working for free newspapers in other countries might be very different, and due to the general paucity of research on journalism in free newspapers, it is very difficult to make generalisations based on this case study. A case study is a way to investigate a complex issue indepth and illuminate a range of different factors that can contribute to answering a particular question. Some of these factors will inevitably be unique to Denmark such as changes in ownership and the considerable impact of competition laws and media support on the selection of news content in Metropress. The broader value of this case study can instead be found in the methodologies used for analysing professional routines of journalists working for a free newspaper and how these journalists are integrated into the broader journalistic profession. All these methods can be used regardless of national context, and if widely applied they would allow us to compare the quality of journalistic work in free newspapers across borders and media systems as well as the quality of free newspapers compared to paid newspapers within national borders.

This research did not receive any specific grant from funding agencies in the public, commercial, or not-for-profit sectors.

\section{References}

Albrecht, J. (2014, 10 April). Her er modtagerne af mediestøtten (Here are the recipients of media support). journalisten.dk. Retrieved from http://journalisten.dk

Andreassen, A. (2013, 6 December). Metroxpress hyrer 10 - vil i spil til Cavlingpriser (Metroxpress hires 10 - aims for Cavling awards). journalisten.dk. Retrieved from http://journalisten.dk

Anmeldelse af Ritzaus aftale om levering af nyhedstjeneste (Notification of Ritzau's agreement for delivering news services). (2005, 30 November). Konkurrencerådet. Retrieved from http://www.forbrug.dk Bakker, P. (2007a). Free Daily Readership. In Worldwide Readership Research Symposia Vienna 2007, pp. 63-74.

Bakker, P. (2007b). Free daily journalism. Anything new? Journalistica, 4, pp. 22-34

Bakker, P. (2008). The simultaneous rise and fall of free and paid newspapers in Europe. Journalism Practice, 3, pp. 427-443.

Bakker, P. (2013). The life cycle of a free newspaper business model in newspaper-rich markets. Journalistica, 1, pp. 33-51.

Bakker, P. (2015, 19 January). No. 8 in a 67-part series: Denmark - a country gone crazy. Newspaper Innovation. Retrieved from http://www.newspaperinnovation.com/

Bilberg, M. (2014, 20 November): Nyhed - Metroxpress overtager driften af tv-skærme i S-togene og på perronerne (News - Metroxpress takes over content production for TV screens on S-trains and platforms). mxmedia.dk. Retrieved from http://mxmedia.dk

Bilberg, M. (2015, 6 February). Metroxpress skifter til "social first" strategi (Metroxpress adopts "social first" strategy). mxmedia.dk. Retrieved from http://mxmedia.dk

Bitsch, L. (2015a, 4 February). Ny 11-mands redaktion skal erobre sociale medier på Metroxpress (11 journalists on new desk aim to conquer social media for Metroxpress). journalisten.dk. Retrieved from http:// journalisten.dk.

Bitsch, L. (2015b, 21 April). Metroxpress satser på følelser, forførelsen og WTF-faktoren (Metroxpress focuses on feelings, seduction and the WTF-factor. journalisten. $d k$. Retrieved from http://journalisten.dk 
Bruun-Hansen, K. (2014). Her er de indstillede til årets FUJ-priser. (Here are the nominees for this year's FUJ awards). journalisten.dk. Retrieved from http://journalisten.dk

Carlsen, C. (2015a, 22 June). Metroxpress gav rekordstort million-underskud $i 2014$ (Record breaking deficit in the millions for Metroxpress in 2014). mediawatch.dk. Retrieved from http://mediawatch.dk.

Carlsen, C. (2015b, 3 December). Citatbarometer: Ekstra Bladet blander sig i top fire (Citation index: Ekstra Bladet moves into top four). mediawatch.dk. Retrieved from http://mediawatch.dk.

Carlsen, C. (2016, 5 January). De mest citerede aviser $i 2015$ (The most quoted newspapers in 2015). mediawatch.dk. Retrieved from http://mediawatch.dk/.

Cavlingforslag 2016 (Cavling nominations 2016). (n.d.). Retrieved from https://journalistforbundet.dk/cavlingforslag-2016.

Danmarks mest lceste dagblad (The most read newspaper in Denmark). (n.d.) Retrieved from http://mxmedia.dk/medier-metroxpress/ Last accessed on 31 March 2017.

Erjavec, K. (2005). Hybrid Public Relations News Discourse. European Journal of Communication, 20 (02), pp. 155-179.

Forslag til Cavlingprisen 2015 (Nominations for the Cavling Prize 2015). (n.d.). Retrieved from https://journalistforbundet.dk/ forslag-til-cavlingprisen-2015.

Fishman, M. (1980). Manufacturing the news. University of Texas Press.

Flensburg, S. (2015). Dansk medistøtte 19602014: Fra økonomisk kompensation til publicistisk motivation (Media subsidies in Denmark 1960-2014: From economic compensation to publicistic motivation). MedieKultur 2015, 58, pp. 85-103

Gratisaviserne 24timer og Metroxpress slår flere redaktionelle funktioner sammen (The free newspapers 24timer and Metroxpress merge a number of editoral functions). (2010, 15 January). mediearbejdsgiverne. $d k$. Retrieved from https://mediearbejdsgiverne.dk.

Haller, M. (2009). Gratis-Tageszeitungen in den Lesermärkten Westeuropas. Nomos Verlag.

Højsgaard, L. (2016, 6 October). Her er årets graverpris-indstillinger. (Here are the nominations for this year's investigative awards). journalisten. $d k$. Retrieved from http://journalisten.dk.

Kammer, A. (2010). Gratisaviserne som en politisk ressource (Free Daily Newspapers as a Political Resource). Journalistica, 2, pp. 28-47.

Lamour, C. (2016). Free Dailies in the European Cross-Border Metropolis: The State-Based Economic Deals. International Journal of Communication, 10, pp. 817-837.

Langergaard, J. (2014, n.d.). Lars Fogt, Anders Borup Sørensen og Jeppe Findalen. journalistforbundet.dk. Retrieved from http://journalistforbundet.dk.

Lund, A. (Ed.) (2000). Først med det sidsteen nyhedsuge i Danmark. (Get the news here - a news week in Denmark). Forlaget Ajour.

Lund, A., Willig I., \& Blach-Ørsten, M. (2009). Hvor kommer nyhederne fra? Den journalistiske fødekcede i Danmark før og nu (Where do the news come from? The journalistic food chain in Denmark before and now). Forlaget Ajour.

Madsen, T. (2016, 14 June). MX-direktør er tilfreds med tocifret millionunderskud. (MX CEO contents himself with double-digit million kroner deficit). mediawatch.dk. Retrieved from http://mediawatch.dk.

McManus, J. (1994). Market-Driven Journalism: Citizens Beware? Sage Publications.

McManus, J. (1997). The First Stage of News Production. Learning What's Happening. In Berkowitz, D. (ed.). Social Meaning of News. A Text-Reader. (pp. 286-299). Sage Publications.

Metroxpress merges with 24timer. (2008, 21 May). Jyllands-Posten. Retrieved from http://jyllands-posten.dk.

Metroxpress relanceres - og 24timer lukker (Metroxpress is relaunched - and 24timer closes). (2013, 14 March). danskemedier.dk Retrieved from http://danskemedier.dk.

Distribution. (Distribution). Retrieved from http://mxmedia.dk/distribution/. Last accessed 31 March 2017.

Om os (About us). (n.d.) Retrieved from http:// mxmedia.dk/om-os/\#redaktionelanker. Last accessed on 31 March 2017.

Oversigt over overenskomster (Directory of collective agreements). (n.d.). Retrieved from https://journalistforbundet.dk/over- 
sigt-over-overenskomster

Last accessed 31 March 2017.

Profil af Metroxpress' loesere 2+3. kvt. 2016 (Profile of Metroxpress' readers 2nd+3rd quarter 2015). (n.d.) Retrieved from https:// issuu.com/metroxpress_as/docs/profil af_metroxpress_1_sere_9843f2c021601f.

Profil af $m x$.dk's brugere September 2016 (Profile of mx.dk's users September 2016). (n.d.) Retrieved from https://issuu.com/ metroxpress_as/docs/mx_online_ profil_september_2016

Skadhede, J. (2017, 11 January). Fusion: BT og MX skærer mindst 23 stillinger væk (Merger: BT and MX cut at least 23 positions). journalisten. $d k$. Retrieved from http://journalisten.dk.

Sparre, K. \& Kabel, L. (2001). Den glade journalistik. Mediernes daekning af de kendte og kongelige (Feelgood journalism. Media coverage of celebrities and royals). Forlaget Ajour.

Stort HPV-tema fra MX: Derfor gør vi det. (MX focuses on HPV: Why we do it). (2015, 8 November). $M X . d k$. Retrieved from https://www.mx.dk.

Swiss 20 Minuten AG buys the Danish commuter newspapers metroXpress and 24timer. ( (2012, 28 November). Retrieved from http://e1.marco.ch/publish/ tamedia/33_2641/20121128_MIT_20_ Minuten-Daenemark-EN.pdf

Søllinge, J. (n.d.) A-pressen. In Den Store Danske (The Big Danish Encyclopedia). Gyldendal. Retrieved from http://denstore danske.dk/index.php?sideId=39347.

The Free Daily Press in Europe 1995-2015: Call for Papers. (n.d.). Retrieved from http:// www.nordicom.gu.se/sites/default/files/ bilder/illustrationer_hs/appel_a_commu nication_presse_gratuite_englishversion. pdf.

Toplisten (The top list). (n.d.) Dansk Online Index. Retrieved from https://doi.tnsclarity.com

Tuchman, G. (1978). Making News. A Study in the Construction of Reality. Free Press.

Vejledning til ansøgning om redaktionel produktionsstøtte i 2016 (Guide to applications for support for editorial production 2016) (2015). Kulturstyrelsen. Retrived from http://slks.dk.
Wadbring, I. (2003). En tidning i tiden? Metro och den svenska dagstidningsmarknaden (A newspaper for its time? Metro and the Swedish newspaper market). JMG, Göteborg University.

Wadbring, I. (2007). The role of free dailies in a segregated society. Nordicom Review 28, pp. 135-147.

Wadbring, I. (2009). Gratis skräp eller demokratisk tillskott?: daglige gratistidninger $i$ Sverige (Free junk or a contribution to democracy? Free newspapers in Sweden). Stiftelsen Institutet för mediestudier.

Walsh, K. (2016, 11 November). BT og Metroxpress går sammen (BT and Metroxpress merge). bt.dk. Retrieved from http://www. bt.dk.

Willig, I., Blach-Ørsten, M., Hartley, J., \& Flensburg, S. (2015). Specialrapport: Journalistiske kvaliteter 1999-2014 (Special report: Journalistic qualities 1999-2014). Kulturstyrelsen. 